\title{
Synthesis of cyclophosphamide metabolites by a peroxygenase from Marasmius rotula for toxicological studies on human cancer cells
}

\author{
Susanne Steinbrecht ${ }^{{ }^{*}+}{ }^{-0}$, Jan Kiebist ${ }^{1,2 \dagger}{ }^{,}$, Rosalie König ${ }^{1,2}$, Markus Thiessen ${ }^{1}$, Kai-Uwe Schmidtke ${ }^{1}$, \\ Sarah Kammerer ${ }^{1}$, Jan-Heiner Küpper ${ }^{1}$ and Katrin Scheibner ${ }^{1}$
}

\begin{abstract}
Cyclophosphamide (CPA) represents a widely used anti-cancer prodrug that is converted by liver cytochrome P450 (CYP) enzymes into the primary metabolite 4-hydroxycyclophosphamide (4-OH-CPA), followed by non-enzymatic generation of the bioactive metabolites phosphoramide mustard and acrolein. The use of human drug metabolites as authentic standards to evaluate their toxicity is essential for drug development. However, the chemical synthesis of 4-OH-CPA is complex and leads to only low yields and undesired side products. In past years, fungal unspecific peroxygenases (UPOs) have raised to powerful biocatalysts. They can exert the identical selective oxyfunctionalization of organic compounds and drugs as known for CYP enzymes with hydrogen peroxide being used as sole cosubstrate. Herein, we report the efficient enzymatic hydroxylation of CPA using the unspecific peroxygenase from Marasmius rotula (MroUPO) in a simple reaction design. Depending on the conditions used the primary liver metabolite 4-OHCPA, its tautomer aldophosphamide (APA) and the overoxidized product 4-ketocyclophosphamide (4-keto-CPA) could be obtained. Using a kinetically controlled approach 4-OH-CPA was isolated with a yield of 32\% (purity >97.6\%). Two human cancer cell lines (HepG2 and MCF-7) were treated with purified 4-OH-CPA produced by MroUPO (4-OH$\left(\mathrm{CPA}^{\mathrm{UPO}}\right) .4-\mathrm{OH}-\mathrm{CPA}^{\mathrm{UPO}}$-induced cytotoxicity as measured by a luminescent cell viability assay and its genotoxicity as measured by $\mathrm{YH} 2 \mathrm{AX}$ foci formation was not significantly different to the commercially available standard. The high yield of 4-OH-CPA UPO and its biological activity demonstrate that UPOs can be efficiently used to produce CYP-specific drug metabolites for pharmacological assessment.
\end{abstract}

Keywords: Biocatalysis, Cyclophosphamide, Human drug metabolites, Peroxygenase, Toxicity

\section{Key Points}

- Unspecific peroxygenase from Marasmius rotula serves as efficient biocatalyst for selective cyclophosphamide hydroxylation.

- Peroxygenase-produced 4-hydroxycyclophosphamide can be used for direct cyto- and genotoxicity evaluation in human cancer cells.

\footnotetext{
*Correspondence: Susanne.Steinbrecht@b-tu.de

tSusanne Steinbrecht and Jan Kiebist are contributed equally to this work ${ }^{1}$ Institute of Biotechnology, Brandenburg University of Technology Cottbus-Senftenberg, Universitätsplatz 1, 01968 Senftenberg, Germany Full list of author information is available at the end of the article
}

\section{Introduction}

Even though xenobiotic metabolism during biotransformation serves mostly as biochemical detoxification process, resulting metabolites might also cause adverse drug reactions and complications (Kirchmair et al. 2015; Park et al. 2011). Therefore, the synthesis of human drug metabolites (HDMs), especially of new drug candidates, plays an important role in pharmaceutical research and for the development of effective and safe drugs. HDMs are required as reference standards for structural confirmation and LC-MS recovery as well as for investigations of their pharmacological and toxicological properties in drug metabolism studies during preclinical
SpringerOpen

(c) The Author(s) 2020. This article is licensed under a Creative Commons Attribution 4.0 International License, which permits use, sharing, adaptation, distribution and reproduction in any medium or format, as long as you give appropriate credit to the original author(s) and the source, provide a link to the Creative Commons licence, and indicate if changes were made. The images or other third party material in this article are included in the article's Creative Commons licence, unless indicated otherwise in a credit line to the material. If material is not included in the article's Creative Commons licence and your intended use is not permitted by statutory regulation or exceeds the permitted use, you will need to obtain permission directly from the copyright holder. To view a copy of this licence, visit http://creativeco mmons.org/licenses/by/4.0/. 
safety assessment (Atrakchi 2009; FDA 2016; Schadt et al. 2018; Walker et al. 2009). Depending on the metabolite structure and chemistry involved, a classical chemical synthesis of HDMs can be very complicated, time and resource consuming (Atzrodt et al. 2012; Derdau et al. 2010).

The main pathway for metabolic clearance of pharmaceuticals is through oxidative mechanism predominantly catalyzed by liver cytochrome P450 monooxygenases (CYPs, EC 1.14.). They introduce in a highly selective manner oxygen into $\mathrm{C}$-H-bonds of complex organic structures in order to convert lipophilic compounds into more hydrophilic and hence more excretable molecules (Guengerich 2008). The portfolio of methods to produce HDMs directly from the parental drug by regio and stereoselective oxyfunctionalization includes conventional oxidation (Chen and White 2010; Litvinas et al. 2009; Shan et al., 2012), biomimetic catalysis (Masood et al. 2012; Nicolas et al. 2013; Piera and Baeckvall 2008), electrochemical oxidation (Madsen et al. 2007; Nouri-Nigjeh et al. 2010) as well as microbial transformations (Amadio et al. 2013; Pervaiz et al. 2013; Sawayama et al. 2009; Schroer et al. 2010; Zollner et al. 2010). However, despite the versatility of those described methods the majority of these reactions are accompanied by low yields and selectivities and often lack also in scalability (Genovino et al. 2016; Zollner et al. 2010).

Unspecific peroxygenases (UPOs, EC 1.11.2.1) secreted by certain fungi have gained attention in the field of oxyfunctionalization. They represent a pronounced superfamily of heme thiolate proteins widespread in fungal kingdom that exhibit a promiscuity for oxygen transfer reactions by incorporating peroxide-derived oxygen into various organic substrates including unactivated hydrocarbons (Hofrichter et al. 2015; Hofrichter and Ullrich 2014; Kiebist et al. 2019). In contrast to membrane-bound, poorly stable and cofactor dependent P450 monooxygenases, secreted UPOs do not require complex cofactors like $\mathrm{NAD}(\mathrm{P}) \mathrm{H}$ or electron-transport systems (flavin-reductases, ferrodoxins) but solely hydrogen peroxide (Hofrichter et al. 2010). The first UPO was isolated from the basidiomycetous fungus Agrocybe aegerita in 2004 (Ullrich et al. 2004). In the following years further representatives were found i.a. in Marasmius rotula and Chaetomium globosum (Gröbe et al. 2011; Kiebist et al. 2017). Next to the handful of isolated and well characterized wild-type UPOs more than 5000 putative UPO sequences have been found in fungal genomes. However, their heterologous expression still seems to be quite difficult to realize and so far successful recombinant expression was only demonstrated in few cases such as in Saccharomyces and Pichia. The limiting steps might be the complex folding and formation of disulfide bridges
(Molina-Espeja et al. 2014, 2015). However, it was shown that UPO-catalyzed reactions generally resemble those of CYPs including hydroxylation, epoxidation, dealkylation, heteroatom oxygenation, $\mathrm{C}-\mathrm{C}$ fission, halide oxidation as well as one-electron oxidation analogously to classic peroxidases (Kiebist et al. 2019). These properties qualify UPOs as an appropriate and convenient tool for the preparative and sustainable production of HDMs as it was demonstrated in a panoply of examples (Gomez de Santos et al. 2018, 2019; Kiebist et al. 2015; Poraj-Kobielska et al. 2013, 2011).

Here, we demonstrate the use of UPOs for metabolite synthesis of the well-known and commonly used cytostatic drug cyclophosphamide (CPA). CPA is used as alkylating agent belonging to the group of oxazaphosphorines and a classic example for a prodrug meaning it is inactive per se until it undergoes metabolic activation to achieve its anti-tumor activity (de Jonge et al. 2005; Fleming 1997; Rodriguez-Antona and IngelmanSundberg 2006). Various human CYP enzymes were shown to hydroxylate CPA resulting in phase I metabolite 4-hydroxycyclophosphamide (4-OH-CPA) that exists in equilibrium with its ring-opened tautomer aldophosphamide (APA). Those tautomers can either be converted into non-cytotoxic metabolites (4-ketocyclophosphamide, 4-carboxycyclophosphamide) or APA decomposes into phosphoramide mustard (PAM) by $\beta$-elimination of acrolein (Fig. 1). PAM is considered to be the primary metabolite responsible for the DNA-alkylating effect of $\mathrm{CPA}$, while acrolein is a toxic by-product (Ahlmann and Hempel 2016; de Jonge et al. 2005). In the present work we aimed to produce 4-OH-CPA using UPOs on semipreparative scale to evaluate the toxicity of those UPOproduced CPA metabolites directly on different human cancer cell lines.

\section{Materials and methods Material and reagents}

4-Ketocyclophosphamide and perfosfamide were purchased from Niomech-IIT GmbH (Bielefeld, Germany). Cyclophosphamide was obtained from Alfa Aesar (Massachusetts, USA) and veratryl alcohol from SigmaAldrich (St. Louis, USA).

All chemicals were reagent-grade purity or analytical standards.

\section{Enzymes}

Unspecific peroxygenases of Agrocybe aegerita (AaeUPO), Coprinellus radians (CraUPO), Marasmius rotula (MroUPO) and Chaetomium globosum (CglUPO) were produced and purified as previously described (Anh et al. 2007; Gröbe et al. 2011; Kiebist et al. 2017; Ullrich et al. 2004). The specific activities were 57, 23, 94 and 8.2 


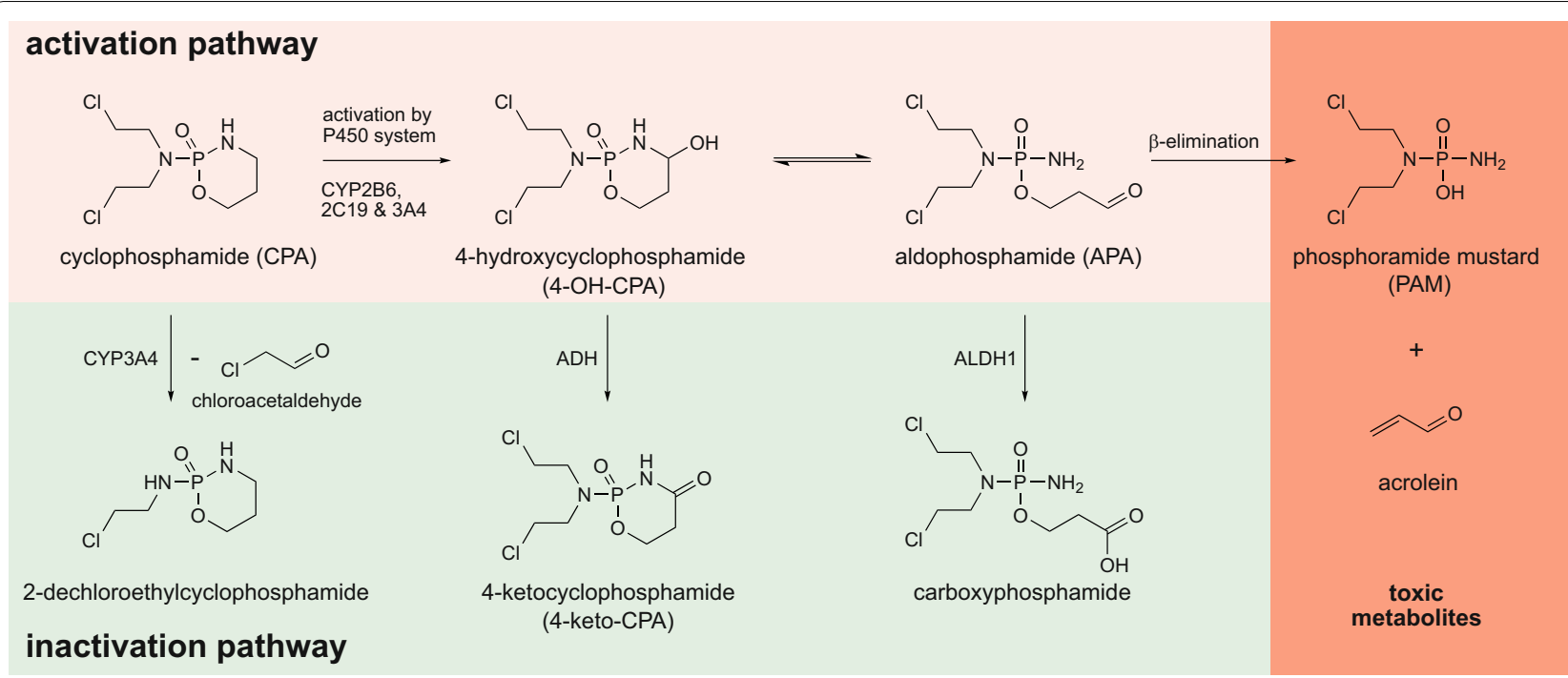

Fig. 1 Metabolism of cyclophosphamide. The activation pathway requires hydroxylation of CPA by the human cytochrome P450 system (especially CYP2B6, -2C19 and -3A4). The primary metabolite 4-OH-CPA is in equilibrium with its tautomer aldophosphamide (APA) that undergoes $\beta$-elimination to the final toxic metabolites phosphoramide mustard (PAM) and acrolein. Through an oxidative reaction catalyzed by alcohol dehydrogenases (ADH) and particularly aldehyde dehydrogenase 1 (ALDH1), 4-OH-CPA and APA are irreversibly deactivated. Figure adapted from de Jonge et al. (de Jonge et al. 2005)

$\mathrm{U} \mathrm{mg}{ }^{-1}$ respectively, whereas $1 \mathrm{U}$ represents the oxidation of $1 \mu \mathrm{mol}$ 3,4-dimethoxybenzyl alcohol. Activities were measured by following the formation of veratraldehyde photometrically at $310 \mathrm{~nm}\left(\varepsilon_{310}=9.3 \mathrm{mM}^{-1} \mathrm{~cm}^{-1}\right)$ in sodium phosphate buffer $(50 \mathrm{mM}, \mathrm{pH} 7$ and $\mathrm{pH} 5.5$ for MroUPO). The oxidation of veratryl alcohol (5 mM) was initiated by adding the cosubstrate hydrogen peroxide $(2 \mathrm{mM})$. Protein content was measured with BCA assay using instructions of the manufacturer (Thermo Fisher Scientific, Germering, Germany). Glucose oxidase (GOx) from Aspergillus niger was purchased from SigmaAldrich (specific activity $215 \mathrm{U} \mathrm{mg}^{-1}$ ).

\section{UPO screening for CPA hydroxylation}

In order to identify the most suitable UPO for preparation of 4-OH-CPA the four enzymes were incubated with CPA whereas a GOx/glucose system was applied for continuous hydrogen peroxide supply. The reaction mixtures (total volume $0.5 \mathrm{~mL}$ ) contained $0.1 \mu \mathrm{M}$ purified UPO in sodium acetate buffer (20 mM, pH 5.5) or BIS-Tris buffer (20 mM, pH 7.0) with CPA (1 mM) and $\alpha$-D-glucose (2\%, $\mathrm{w} / \mathrm{v})$. Reactions were started by addition of $1 \mathrm{nM} \mathrm{GOx}$, stirred at $25^{\circ} \mathrm{C}$ for $4 \mathrm{~h}$ and were stopped by the addition of $500 \mu \mathrm{L}$ cooled acetonitrile $\left(-20^{\circ} \mathrm{C}\right)$. The mixtures were centrifuged at $12,000 \mathrm{~g}$ for $10 \mathrm{~min}$ and subsequently analyzed by HPLC as described below. All reactions were performed in triplicate plus separated blanks without $\mathrm{UPO}$ and without GOx.
The HPLC system (VWR Hitachi) comprised L-2130 pump, L-220 autosampler, L-2300 column oven and L-2455 DAD coupled with a low temperature evaporative light scattering detector (ELSD 100, VWR, Radnor, PA, USA). Separation was performed on a Kinetex ${ }^{\circledR}$ column $(\mathrm{C} 18,5 \mu \mathrm{m}, 100 \AA$, $150 \times 4.6 \mathrm{~mm}$, Phenomenex) with mobile phase A $\left(\mathrm{diH}_{2} \mathrm{O}\right)$ and $\mathrm{B}$ (acetonitrile) using following gradient at a flow rate of $1 \mathrm{~mL} \mathrm{~min}^{-1}: 5 \% \mathrm{~B}$ at $0-2 \mathrm{~min} ; 5-50 \% \mathrm{~B}$ at $2-20 \mathrm{~min} ; 50 \% \mathrm{~B}$ at $20-22 \mathrm{~min}$; $50-5 \% \mathrm{~B}$ at $22-24 \mathrm{~min}$ and $5 \% \mathrm{~B}$ at $24-26 \mathrm{~min}$. Analytes were identified using authentic standards and highresolution mass spectrometry (HRMS). Commercially available compound perfosfamide (PPA, 4-hydroperoxycyclophosphamide) served as standard for 4-OH-CPA. PPA was reduced by addition of sodium thiosulphate beforehand as given by manufactures instructions (Niomech-IIT GmbH, Bielefeld, Germany).

Chromatographic separation for LC-MS experiments were performed on a Thermo Scientific Vanquish Flex Quaternary UHPLC system (Thermo Fisher Scientific). The chromatographic column, eluents and gradient applied were the same as described before. The flow rate

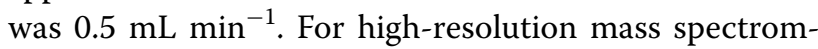
etry (HRMS), a Thermo Scientific Q Exactive Plus quadrupole-Orbitrap mass spectrometer (Thermo Electron, Bremen, Germany) coupled with a heated electrospray ionization source in positive mode was used. The tune operating parameters were as follows: the rate of sheath gas flow and auxiliary gas flow was 60 and 15 (arbitrary 
unit), respectively; spray voltage $4.0 \mathrm{kV}$; the temperature of capillary and auxiliary gas heater was $320^{\circ} \mathrm{C}$ and $400{ }^{\circ} \mathrm{C}$, respectively; high-resolution $\mathrm{MS}^{\mathrm{n}}$ was operated at full scan with a mass range of $m / z 150-1500$ at a resolution of 70,000 $(\mathrm{m} / z 200)$.

\section{Semi-preparative synthesis of 4-hydroxycyclophosphamide}

Initially, to monitor the reaction course and to determine the optimal time to stop the CPA conversion in order to obtain a high yield of desired 4-OH-CPA and a reduced side product formation, the approach was carried out in 5-mL-scale. Therefore $13 \mathrm{mg}$ CPA $(0.05 \mathrm{mmol})$ were dissolved in sodium acetate buffer $(20 \mathrm{mM}, \mathrm{pH} 5.5)$ and $1 \mu \mathrm{M}$ MroUPO was added. The reaction was started by adding the cosubstrate hydrogen peroxide by a syringe pump (Harvard Apparatus Pump11, $5 \mathrm{mM} \mathrm{h}^{-1}$ ) while stirring at $100 \mathrm{rpm}$ and incubating at $25{ }^{\circ} \mathrm{C}$. Samples $(2 \times 100 \mu \mathrm{L})$ were taken from the reaction mixture every $60 \mathrm{~min} ; 100 \mu \mathrm{L}$ were used to determine the remaining MroUPO activity by veratryl alcohol assay (as described above), whereas the other $100 \mu \mathrm{L}$ were diluted with $100 \mu \mathrm{L}$ acetonitrile $\left(-20^{\circ} \mathrm{C}\right)$, centrifuged for $10 \mathrm{~min}$ at $13,000 \mathrm{~g}$ and served to monitor metabolite formation by HPLC-ELSD.

Based on the results of the before mentioned approach the reaction was linearly scaled up to $100 \mathrm{~mL}$-scale. Cyclophosphamide (261 mg, $1 \mathrm{mmol}$ ) was dissolved in sodium acetate buffer $(20 \mathrm{mM}, \mathrm{pH} 5.5)$ with $1 \mu \mathrm{M}$ MroUPO, and the reaction was initiated by continuous supply of hydrogen peroxide $\left(5 \mathrm{mM} \mathrm{h}^{-1}\right)$. The reaction was stirred at $25^{\circ} \mathrm{C}$ for $1 \mathrm{~h}$. To stop the reaction $50 \mathrm{~mL}$ chloroform were added for $1 \mathrm{~min}$. The phases were separated and the aqueous phase was extracted twice with chloroform $(2 \times 25 \mathrm{~mL})$ and dried with $\mathrm{Na}_{2} \mathrm{SO}_{4}$. The aqueous phase was concentrated by column chromatography using $\mathrm{C}_{18}$-silica gel (90 $\AA, 230-400$ mesh, Sigma-Aldrich). After elution of 4-OH-CPA with acetonitrile the solvent was removed under vacuum and subsequently subjected to preparative HPLC. Purification was conducted on a Shimadzu LC-20AP (Shimadzu, Japan) equipped with a FRC-10 A fraction collector, LC20AP pump, SPD-10 A detector, and LiChrospher ${ }^{\circledR} 100$ column $\left(\right.$ LiCART $^{\circledR}, 250 \times 10 \mathrm{~mm}, \mathrm{RP}-18,10 \mu \mathrm{m}$, Merck KGaA, Darmstadt, Germany). Data analysis was performed using LC-2000 systems software. The injection volume was $2 \mathrm{~mL}$ and the mobile phase consisted of deionized water (A) and acetonitrile (B), with a gradient elution program similar as described for analytical HPLC above using a flow of $5 \mathrm{~mL} \mathrm{~min}{ }^{-1}$. Fractions were collected, cooled on ice and analyzed by HPLC-ELSD. 4-OH-CPA containing fraction were pooled, acetonitrile was removed under vacuum and the aqueous solution was frozen at $-80{ }^{\circ} \mathrm{C}$ and finally concentrated by lyophilization. Purification by preparative HPLC yielded in $89 \mathrm{mg}(32 \%)$ of a white powder with a purity of $97.6 \%$ (HPLC-ELSD).

HRMS $\left(\mathrm{ESI}^{+}\right): \mathrm{m} / z$ calculated for $\mathrm{C}_{7} \mathrm{H}_{16} \mathrm{Cl}_{2} \mathrm{~N}_{2} \mathrm{O}_{3} \mathrm{P}$ $[\mathrm{M}+\mathrm{H}]^{+}:$:277.0276, found: $277.0268[\mathrm{M}+\mathrm{H}]^{+}(100 \%)$; $m / z$ calculated for $\mathrm{C}_{7} \mathrm{H}_{14} \mathrm{Cl}_{2} \mathrm{~N}_{2} \mathrm{O}_{2} \mathrm{P} \quad\left[\mathrm{M}+\mathrm{H}-\mathrm{H}_{2} \mathrm{O}\right]^{+}$: 259.0169, found: $259.0163\left[\mathrm{M}+\mathrm{H}-\mathrm{H}_{2} \mathrm{O}\right]^{+}(90 \%)$.

Stability of the synthesized 4-OH-CPA by MroUPO (4-OH-CPA ${ }^{\mathrm{UPO}}$ ) was examined in aqueous dilutions which were kept at $37{ }^{\circ} \mathrm{C}$ for $24 \mathrm{~h}$ or at $-80{ }^{\circ} \mathrm{C}$ for 4 weeks. Samples were analyzed by HPLC-ELSD.

\section{Cell culture}

Human breast adenocarcinoma (MCF-7; ATCC: HTB22, Manassas, USA) and human hepatoblastoma (HepG2; ATCC: HB-8065) cells were cultivated in Dulbecco's minimal essential medium (DMEM) (Biochrom AG, Berlin, Germany) supplemented with $10 \%$ fetal bovine serum (Biochrom AG) and $2 \mathrm{mM} \mathrm{L-glutamine} \mathrm{(PAA} \mathrm{Laborato-}$ ries $\mathrm{GmbH}$, Pasching, Austria) at $37{ }^{\circ} \mathrm{C}$ and $5 \% \mathrm{CO}_{2}$ in a humidified incubator. For the experiments described we used passages 14-21 for HepG2 and 13-33 for MCF-7 cells.

\section{CellTiter-Glo ${ }^{\circledR} 2.0$ assay}

HepG2 and MCF-7 cells were seeded at a density of $1.5 \times 10^{4}$ cells per well in 96-well plates (Sarstedt AG \& Co). After $24 \mathrm{~h}$, cells were treated with ten different concentrations of cyclophosphamide (CPA), perfosfamide (PPA) or 4-OH-CPA ${ }^{\mathrm{UPO}}$ at a range of $0-1.6 \mathrm{mM}$ for HepG2 cells and 0-400 $\mu \mathrm{M}$ for MCF-7 cells in standard medium. We found in previous experiments these concentration ranges to be optimal for $\mathrm{EC}_{50}$ determination for both cell lines. $24 \mathrm{~h}$ after substance treatment, evaluation of cell viability was performed using CellTiterGlo ${ }^{\circledR} 2.0$ assay (Promega, Madison; USA) according to the manufacturer's protocol. In short, substance-containing medium was replaced by $100 \mu \mathrm{L}$ reaction mixture $(50 \mu \mathrm{L}$ fresh medium supplemented with $50 \mu \mathrm{L}$ ATP reagent solution). Plates were shaken at $300 \mathrm{rpm}$ for $2 \mathrm{~min}$ and then incubated for $10 \mathrm{~min}$ at room temperature in the dark. Lysates were transferred to a white-walled 96-well plate and luminescence signals were measured using FLUOstar Omega microplate reader (BMG Labtech, Ortenberg, Germany). The $\mathrm{EC}_{50}$ values were derived from three separate and distinct experiments, whereby the repetitions within each experiment were averaged. Statistical data analysis and nonlinear regression for determination of $\mathrm{EC}_{50}$ values (half maximum effective concentration) were performed using GraphPad Prism 6.0 (GraphPad Software Inc., San Diego, CA, USA). The 
Mann-Whitney $\mathrm{U}$ test was used to compare the $\mathrm{EC}_{50}$ values. $P$ value $<0.05$ was considered statistically significant.

\section{Detection of $\mathrm{\gamma H} 2 \mathrm{AX}$ foci}

HepG2 $\left(1.5 \times 10^{4}\right)$ and MCF-7 $\left(2.5 \times 10^{4}\right)$ cells were seeded onto glass cover slips in 24-well plates (Sarstedt AG \& Co). After $24 \mathrm{~h}$, cells were treated with three different concentrations of CPA, PPA or 4-OH-CPA ${ }^{\mathrm{UPO}}$ at a range of $0-50 \mu \mathrm{M}$ for HepG2 cells and $0-25 \mu \mathrm{M}$ for MCF-7 cells in standard medium. $24 \mathrm{~h}$ after substance treatment, cells were fixed in $4 \%$ paraformaldehyde (Merck Millipore, Massachusetts, USA) for $10 \mathrm{~min}$, washed with PBS and permeabilized in $0.25 \%$ Triton X-100 (Carl Roth $\mathrm{GmbH}$ ) for 3 min. After washing with PBS, cells were incubated for $1 \mathrm{~h}$ at RT with antiphospho-Histone H2A.X (Ser139) mouse monoclonal IgG (clone JBW301, Cat. No. 05-636, Merck Millipore) diluted 1:1000 in PBS containing 1\% BSA. After washing, cells were incubated for $1 \mathrm{~h}$ at RT with polyclonal Cy3conjugated goat-anti-mouse antibody (Jackson ImmunoResearch Laboratories, Inc., West Grove) diluted 1:200 in PBS containing $1 \% \mathrm{BSA}$ and $0.2 \mu \mathrm{g} \mathrm{mL}{ }^{-1}$ DAPI (Carl Roth $\mathrm{GmbH})$. Immunofluorescence was evaluated with an Olympus IX81 fluorescence microscope (Olympus, Tokyo, Japan).

\section{Results}

\section{Human CPA metabolites produced by MroUPO}

Four unspecific peroxygenases secreted by different fungi were tested for their ability to selectively oxyfunctionalize cyclophosphamide (CPA). The reaction mixtures were analyzed by HPLC-ELSD and the formed products determined by HRMS using authentic standards of 4-ketocyclophosphamide (4-keto-CPA) and reduced perphosphamide (PPA). The latter is a peroxidized CPA derivative that can be reduced to 4-OH-CPA using sodium thiosulphate (Hilton, 1984).

All UPOs tested were able to hydroxylate CPA to form 4-OH-CPA, but with distinctly different yields. The most promising biocatalyst for the target reaction was MroUPO (22\%) followed by CraUPO (14\%), CglUPO (4\%) and AaeUPO (3\%) (Fig. 2). Other than the following products were not found with the tested enzymes. Along with the formation of 4-OH-CPA by MroUPO (HRMS calcd. for $\mathrm{C}_{7} \mathrm{H}_{16} \mathrm{Cl}_{2} \mathrm{~N}_{2} \mathrm{O}_{3} \mathrm{P}[\mathrm{M}+\mathrm{H}]^{+}$: 277.0276, found 277.0269) also its tautomer aldophosphamide (APA) and to a minor extend the side product 4-ketocyclophosphamide (4-keto-CPA, HRMS calcd. for $\mathrm{C}_{7} \mathrm{H}_{14} \mathrm{Cl}_{2} \mathrm{~N}_{2} \mathrm{O}_{3} \mathrm{P}$ $[\mathrm{M}+\mathrm{H}]^{+}:$275.0119, found 275.0111) could be detected indicating an overoxidation of 4-OH-CPA (Scheme 1). Since 4-OH-CPA and APA equilibrate with each, the term 4-OH-CPA denote both compounds.

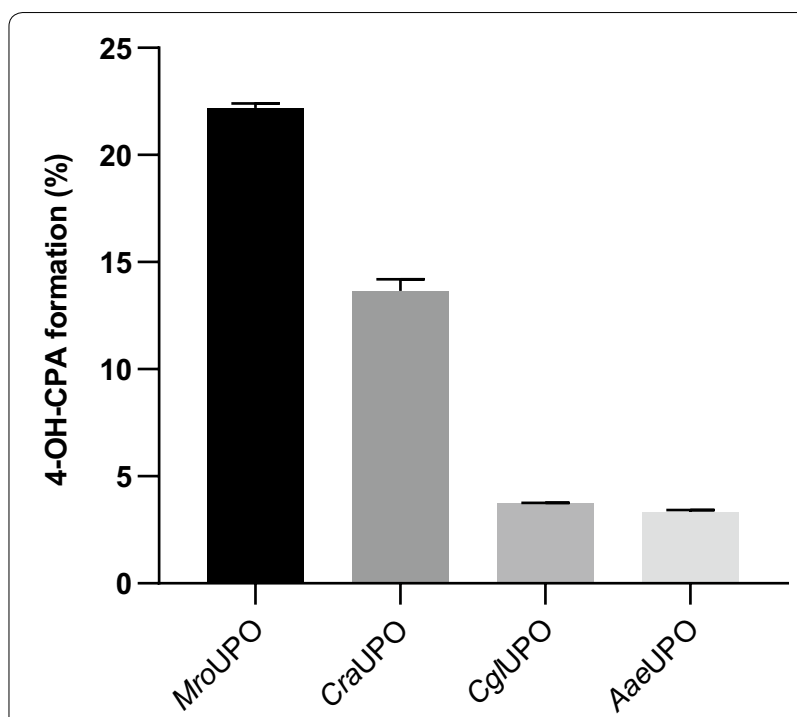

Fig. 2 UPO screening for 4-OH-CPA production. The diagram displays the yield of 4-OH-CPA produced by different wild-type UPOs within 4 h using following conditions: $0.1 \mu \mathrm{M}$ purified UPO, $1 \mathrm{nM}$ GOx, $1 \mathrm{mM}$ CPA, 2 wt $\%$ glucose, pH 5.5 (in case of MroUPO) or 7.0 and $25^{\circ} \mathrm{C}$. The data represent mean values of three independent approaches with standard error of the mean (SEM)

Kinetically controlled enzymatic synthesis of 4-OH-CPA

Because of its superior metabolization activity of CPA, further investigations for 4-OH-CPA production was carried out with MroUPO. In a small-scale approach $(5 \mathrm{~mL}$ total volume) different parameters were varied including substrate-catalyst ratio and hydrogen peroxide supply (data not shown). The best conditions were used to follow the course of the metabolite formation by HPLCELSD indicating a high influence to the metabolite ratio by the reaction time (Fig. 3b). At the beginning, mainly 4-OH-CPA was formed (45\%) and at a small extend also APA and 4-keto-CPA (Fig. 3a-A). Already after $2 \mathrm{~h}$ reaction time, the yield of 4-OH-CPA reached its maximum around 52\% (turnover frequency (TOF) 3,000 $\mathrm{h}^{-1}$ ) while $10 \%$ APA and 4-keto-CPA were present, respectively. As the reaction proceeded, the concentration of 4-ketoCPA increased significantly within the next two hours, whereby the ratio of 4-OH-CPA and APA remained constant resulting in a total turnover number (TTN) value for C4-oxidation of about 10,000.

Since the main objective was to produce the primary CPA metabolite 4-OH-CPA by selective incorporation of oxygen using MroUPO, a reaction time of $60 \mathrm{~min}$ was chosen for the semi-preparative scale based on the results given before. The reaction was stopped by adding chloroform yielding in 42\% 4-OH-CPA and a small fraction of the side product 4-keto-CPA. To obtain the primary metabolite $4-\mathrm{OH}-\mathrm{CPA}$ at high purity, the reaction 


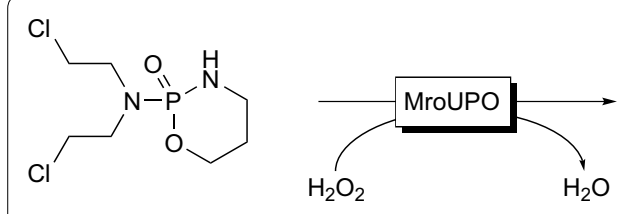

cyclophosphamide (CPA)<smiles>O=P1(N(CCCl)CCCl)NC(O)CCO1</smiles>

4-hydroxycyclophosphamide (4-OH-CPA)

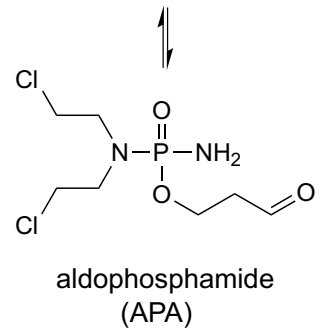

(APA)

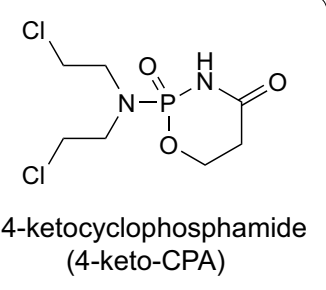

4-ketocyclophosphamide (4-keto-CPA)

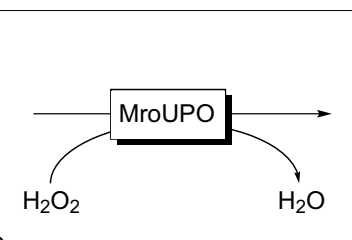

Scheme 1 Cyclophosphamide converted by MroUPO to human drug metabolites. MroUPO transformed of cyclophosphamide (CPA) into the intrinsic active metabolite 4-hydroxy-cyclophsophamide (4-OH-CPA), its tautomer aldophosphamide (APA) and the overoxidized side product 4-ketocyclophsophamide (4-keto-CPA)

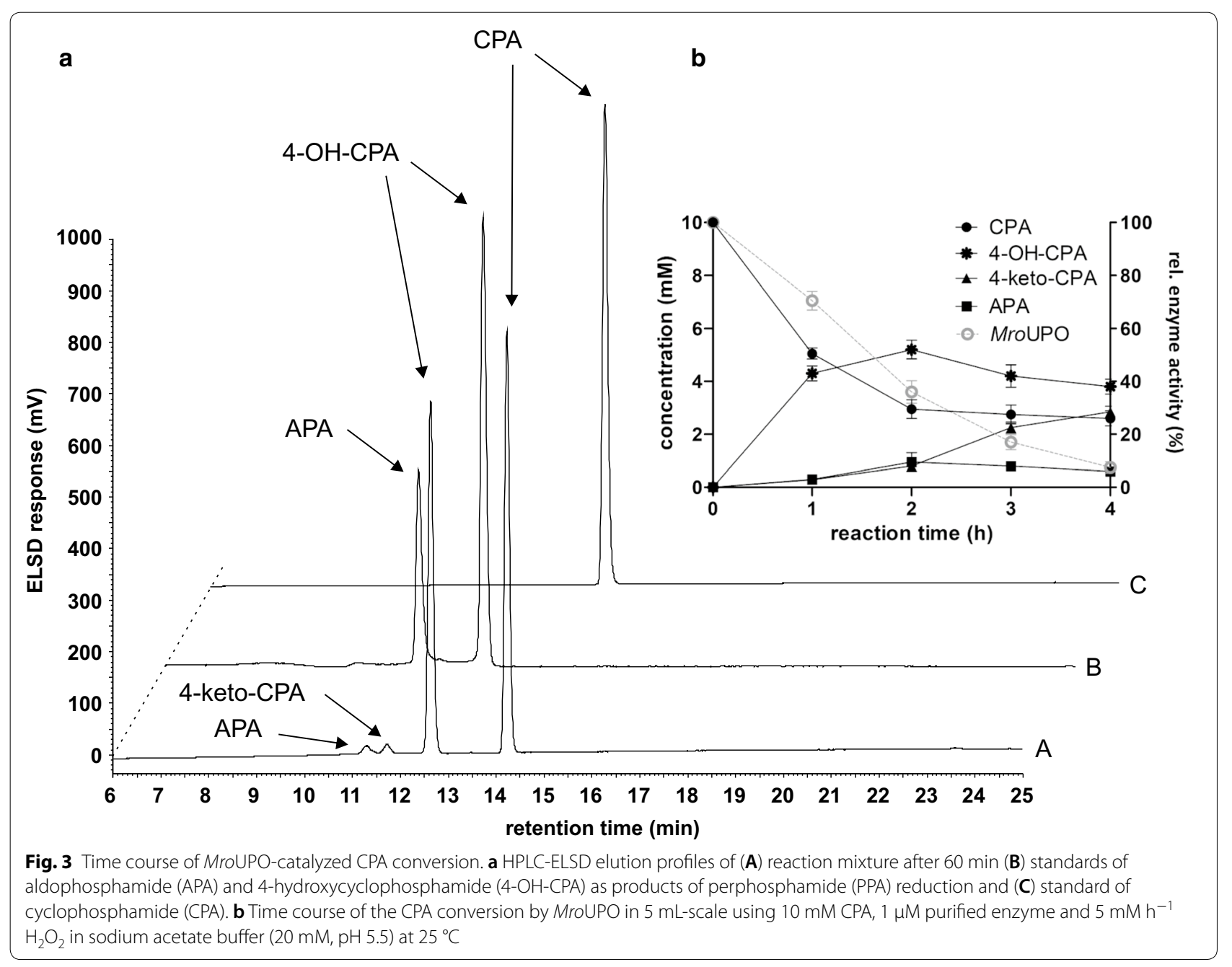


mixture was extracted, concentrated and purified by preparative HPLC. The purified fractions were further analyzed by HPLC-ELSD, accordingly pooled and finally the solvent was removed. As final product we achieved approximately $89 \mathrm{mg}$ white solid of tautomers 4-OHCPA and APA with a purity of $97.6 \%$ (HPLC-ELSD).

\section{4-OH-CPA UPO affects human cancer cell lines as its synthetic counterpart PPA}

According to literature, 4-OH-CPA is in equilibrium with APA and decomposes into the cytotoxic compounds PAM and acrolein (Fig. 1) (de Jonge et al. 2005). While the therapeutic anti-cancer effect of CPA is attributed to the DNA-crosslinking metabolite PAM, acrolein causes toxic side effects through the production of highly reactive oxygen free radicals (Omole et al. 2018). Before incubation with cells, we tested by HPLC analysis the stability of MroUPO-produced 4-OH-CPA (4-OH-CPA ${ }^{\mathrm{UPO}}$ ) at different temperatures. While 4-OH-CPA ${ }^{\mathrm{UPO}}$ decayed almost completely at $37^{\circ} \mathrm{C}$ within $24 \mathrm{~h}$, the metabolite was stable at $-80^{\circ} \mathrm{C}$ for at least one month after purification (data not shown). Therefore, 4-OH-CPA ${ }^{\mathrm{UPO}}$ was kept frozen at $-80{ }^{\circ} \mathrm{C}$ and thawed shortly before starting the cell experiments. We tested the biological effect of 4-OH$\mathrm{CPA}^{\mathrm{UPO}}$ on metabolic activity of two different human cancer cell lines, HepG2 and MCF-7. We exposed those cell lines to different concentrations of purified 4-OH$\mathrm{CPA}^{\mathrm{UPO}}$, the commercial standard PPA and unconverted CPA for $24 \mathrm{~h}$. PPA decomposes rapidly into 4-OH-CPA in aqueous solution at $37^{\circ} \mathrm{C}$ and its effects were therefore directly compared to those of 4-OH-CPA ${ }^{\mathrm{UPO}}$ (Low et al. 1982). Microscopic examination showed that the cell morphology of both cell lines changed dramatically after treatment with 4-OH-CPA ${ }^{\mathrm{UPO}}$ or PPA (Fig. 4a, b, middle and lower panels). While HepG2 and MCF-7 cells appeared unaltered after respective CPA treatment (Fig. 4a, b, upper panels), the cells exposed to the metabolite were rounded and detached from the cell culture flask as expected for cytotoxic compounds.

To compare the cytotoxic effects of all three compounds on human cancer cells, we performed a standard ATP assay and calculated $\mathrm{EC}_{50}$ values. $\mathrm{CPA}$, up to the highest concentration used, did not result in any (HepG2) or only a slight (MCF-7) reduction of relative ATP levels (Fig. 4c, d). In contrast, treatment with 4-OH-CPA ${ }^{\mathrm{UPO}}$ and commercial PPA led to complete ATP depletion in both cell lines at higher concentrations, indicating cell death. There was no significant difference between $\mathrm{EC}_{50}$ values of 4-OH-CPA ${ }^{\mathrm{UPO}}$ and PPA in both cell lines. $\mathrm{EC}_{50}$ values for HepG2 were between 111 and $113 \mu \mathrm{M}$ (Fig. 4c), while MCF-7 cells responded more sensitively to 4-OH$\mathrm{CPA}^{\mathrm{UPO}}$ and PPA treatment with lower $\mathrm{EC}_{50}$ values of 28 and $33 \mu \mathrm{M}$, respectively (Fig. 4d).
To directly analyze genotoxicity of 4-OH-CPA ${ }^{\mathrm{UPO}}$, we investigated the formation of $\gamma \mathrm{H} 2 \mathrm{AX}$ foci using indirect immunofluorescence. After exposure of cancer cells to $\mathrm{CPA}, 4-\mathrm{OH}-\mathrm{CPA}{ }^{\mathrm{UPO}}$, as well as the PPA in concentrations up to $50 \mu \mathrm{M}$ for HepG2 and $25 \mu \mathrm{M}$ for MCF-7 for $24 \mathrm{~h}$, the phosphorylation of $\mathrm{H} 2 \mathrm{AX}(\gamma \mathrm{H} 2 \mathrm{AX})$, seen as fluorescent foci in cell nuclei, was measured. Cells treated with increasing concentrations of prodrug CPA did not show any significant formation of $\gamma \mathrm{H} 2 \mathrm{AX}$ foci (Fig. 5a, b, upper panels). In contrast, nuclei of both cell lines showed a clear concentration-dependent increase in $\gamma \mathrm{H} 2 \mathrm{AX}$ foci formation after treatment with $\mathrm{PPA}$ and 4-OH-CPA $\mathrm{UPO}$ (Fig. 5a, b, middle and lower panels).

\section{Discussion}

The U.S. Food and Drug Administration (FDA) clearly recommends the identification and characterization of drug metabolites for nonclinical safety assessments during early drug development prior to the first human studies (FDA 2016). Usually, standard animal experiments for toxicological drug testing are used in these nonclinical safety evaluations. However, the metabolite profiles can differ from species to species both qualitatively and quantitatively. Therefore, the identification of major human drug metabolites (HDMs) and approaches for their synthesis are essential in order to use them for further in vitro and in vivo evaluations of their pharmacological and toxicological consequences (Baillie et al. 2002; FDA 2016; Nedderman 2009). An efficient approach in the production of drug metabolites on a preparative scale is the use of native human CYPs as biocatalysts (Bernhardt and Urlacher 2014). The range extends from whole cell systems such as CYP-overexpressing human cell lines, recombinant expression of individual human CYP isoforms in different microorganisms up to isolated liver microsomes (Schroer et al. 2010; Steinbrecht et al. 2019a). Since the use of whole cell systems is restricted, for instance, by low expression levels of certain CYP isoforms and limitations in substrate uptake and product transport, simplified biocatalysis using isolated enzymes have been developed (Schroer et al. 2010; Urlacher and Girhard 2012). Besides the use of cytosolic bacterial CYP enzymes, in the recent years the enzyme class of unspecific peroxygenases (UPOs) has proven to be a large activation toolbox for several pharmaceutical agents due to their metabolic similarities to human cytochrome P450 enzymes. Successful drug conversion by UPOs into their known metabolites was demonstrated for example with diclofenac, ibuprofen, propranolol, naproxen, sildenafil, volixibat and testosterone (Kiebist et al. 2019, 2015, 2017; Kinne et al. 2009; Poraj-Kobielska et al. 2011). 

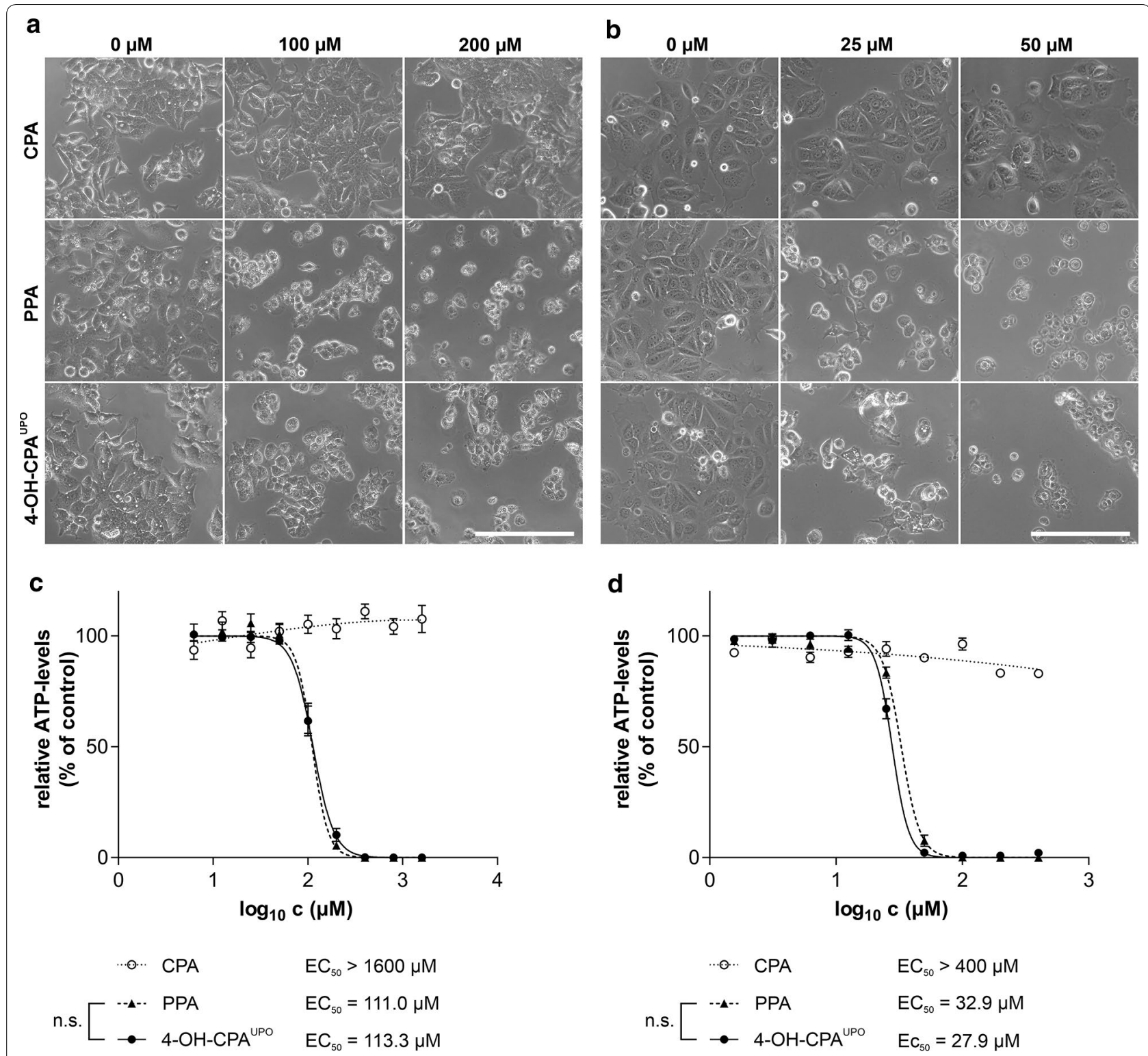

Fig. 4 Morphology and metabolic activity of HepG2 and MCF-7 cells treated with CPA, PPA or 4-OH-CPA UPO. Cells were treated with different concentrations of the compounds for $24 \mathrm{~h}$. Phase contrast images of (a) HepG2 and (b) MCF-7 cells were obtained with microscope CKX41 and $20 \times$ objective (scale bar $200 \mu$ m). Relative viabilities of treated (c) HepG2 and (d) MCF-7 cells were evaluated by CellTiter-Glo ${ }^{\circledR} 2.0$ assay (as ATP levels). Data represent mean values \pm SEM relative to untreated controls of three independent experiments in triplicates. Calculated $\mathrm{EC}_{50}$ values are indicated; n.s.: not significant

Here, we were interested to go a significant step forward, i.e. to compare the biological effects on human target cells of an UPO-produced metabolite with its commercially available synthetic counterpart. For this we studied the conversion of cyclophosphamide, a model drug for bioactivation, by selective hydroxylation at C-4 catalyzed by an UPO secreted from agaric fungus Marasmius rotula (MroUPO). HPLC-ELSD analyses and comparison with commercial standards showed an enzymatic conversion of CPA resulting in a time-dependent formation of the main product 4-hydroxycyclophosphamide (4-OH-CPA), the corresponding tautomer aldophosphamide (APA), and the overoxidized side product 4-ketocyclophosphamide (4-keto-CPA). CPA oxyfunctionalization by hydroxylation reflects the main activation pathway of CPA described in the literature, which is catalyzed in vivo by various human CYPs such as CYP2A6, 2B6, 3A4/5, 2C9, 2C8, 2C18 and 2C19 (Fig. 1) 


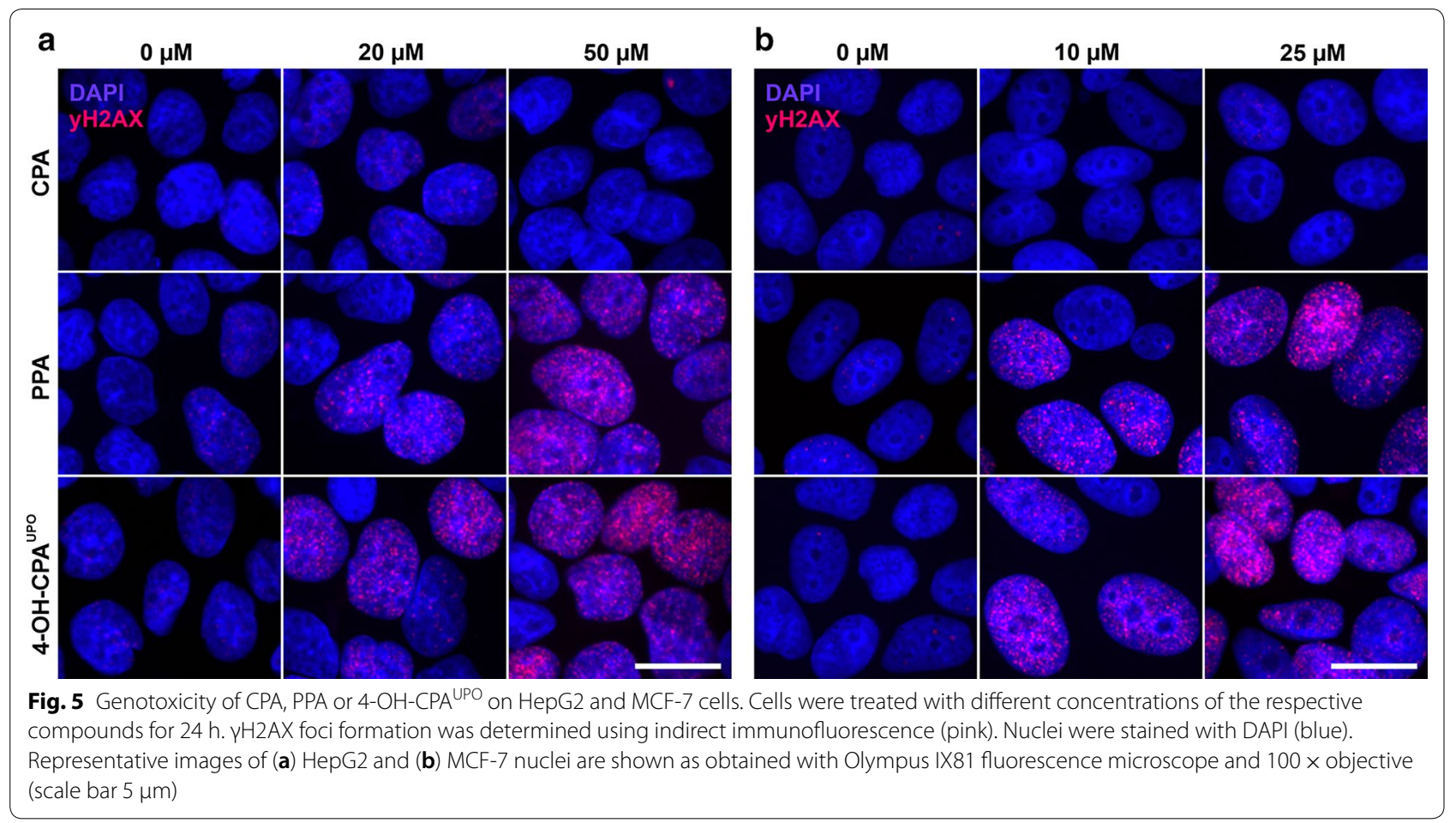

(Chang et al., 1993; Chang et al., 1997a, b; Ren et al., 1997; Xie et al., 2003). However, the use of human liver microsomes to convert CPA into its known human metabolites was shown to result in only in low yields (Chang, et al., 1993; Choi et al., 2015).

Synthetical production of 4-OH-CPA by conventional chemical methods dates back to the 1970s and describes the preparation of perfosfamide (PPA, 4-hydroperoxycyclophosphamide) as a precursor that intracellularly decays to 4-OH-CPA. PPA can be produced by Fenton oxidation of CPA, which uses $\mathrm{Fe}^{2+}$ ions as iron(II) sulphate and hydrogen peroxide in an acidic solution. This oxidation method achieved a yield of only 3-4\% PPA and 11\% 4-keto-CPA (van der Steen et al., 1973). Direct ozonation of cyclophosphamide or of $\mathrm{O}$-3-butenyl- $\mathrm{N}, \mathrm{N}$ bis(2-chloroethyl)-phosphordamidate is another option for PPA synthesis in only one step. Ozonation of CPA gave a yield of 20\% PPA and 50\% 4-keto-CPA.(Hohorst et al., 1976) Takamizawa et al. further described an ozone-based method with a high PPA output of 50-60\%, which resulted in about 40\% 4-OH-CPA after deoxygenation (Takamizawa et al. 1975).

After $60 \mathrm{~min}$ of CPA conversion with MroUPO, we achieved a $4-\mathrm{OH}-\mathrm{CPA}$ yield of $42 \%$ with less than $3 \%$ of the undesired by-product 4-keto-CPA. Thus, the enzymatic method presented here using unspecific peroxygenases reveals to be competitive with conventional chemical methods concerning the yield of 4-OH-CPA.
Regarding the low amount of unwanted 4-keto-CPA, the reaction catalyzed by MroUPO has even proved to be superior. In addition, due to the enzymatic conversion under mild conditions, instead of using aggressive oxidants, the regioselectivity of hydroxylation is more precise and no special safety instructions are required during performance.

Purified 4-OH-CPA ${ }^{\mathrm{UPO}}$ was used to treat the cancer cell lines HepG2 and MCF-7 for re-evaluation of CPA and its metabolite toxicity. Since 4-OH-CPA is known to be very unstable with a half-life of only a few minutes in plasma at $37{ }^{\circ} \mathrm{C}$, we were interested in metabolite stability under the experimental conditions we used (de Jonge et al. 2005; Johansson and Bielenstein 1994). In stability analysis of 4-OH-CPA ${ }^{\mathrm{UPO}}$ we detected an almost complete degradation after $24 \mathrm{~h}$ at $37^{\circ} \mathrm{C}$ in aqueous solution (data not shown). At $-80{ }^{\circ} \mathrm{C}$, however, 4-OH-CPA UPO remained stable for at least one month, so storage at this temperature was recommended.

In this study we aimed to compare the cytotoxic effect of 4-OH-CPA ${ }^{\mathrm{UPO}}$ on human cancer cells with that of commercially available PPA and the parental substance CPA using a $24 \mathrm{~h}$ incubation period. PPA exhibits higher stability and is often used as an alternative to 4-OH-CPA. It can be equated with the use of 4-OH-CPA due to its rapid degradation into 4-OH-CPA in aqueous solution and has the same toxicity (Hales 1982; Hohorst et al. 1976; Johansson and Bielenstein 1994; Peter and Hohorst 
1979). Low et al. described that PPA is converted to 4-OH-CPA at $\mathrm{pH} 7.4$ and $37{ }^{\circ} \mathrm{C}$ (corresponds to cell culture conditions) with a $t_{1 / 2}$ of 43 min (Low et al. 1982).

CPA is commonly used to treat various types of autoimmune and neoplastic diseases, including breast cancer. Since breast cancer cell line MCF-7 is commonly used to study antitumor drugs, it provides a suitable cell model for the assessment of CPA metabolite therapeutic effects (Kars et al. 2006; Li et al. 2001; Prados et al. 2010; ShuiTein Chen 2002; Trebunova et al. 2012). HepG2 cells, on the other hand, were most frequently used as human liver cell model for toxicity studies and can contribute to the risk assessment of drug-induced liver injury (Brandon et al. 2003; Yokoyama et al. 2018). Although they exhibit negligible activity of most xenobiotic metabolizing enzymes, HepG2 cells retained several hepatocytespecific characteristics (Javitt 1990; Knowles et al. 1980).

Dose dependently, short-term exposure $(24 \mathrm{~h})$ of HepG2 and MCF-7 cells to 4-OH-CPA ${ }^{\mathrm{UPO}}$ or PPA resulted in a dramatic change in cell morphology and a complete reduction of metabolic activity (Fig. 4). Within the cell 4-OH-CPA decays to phosphoramid mustard (PAM), which is a bifunctional DNA alkylating agent causing intra- and interstrand cross-links and DNA double-strand breaks that can kill dividing cells. It is well known that DNA double-strand break formation is accompanied by phosphorylation of histone H2AX $(\gamma \mathrm{H} 2 \mathrm{AX})$ (Ganesan and Keating 2015; Scharer 2005). After immunofluorescence staining of emerging nuclear $\gamma \mathrm{H} 2 \mathrm{AX}$ foci in 4-OH-CPA ${ }^{\mathrm{UPO}}$ and PPA-treated cells, the genotoxicity via PAM of those substances could be demonstrated (Fig. 5). With parental drug CPA, almost no toxic effect on cell morphology, metabolic activity or DNA double-strand break formation could be detected in the concentration range used. Therefore, basal expression of human CYPs involved in drug metabolism in HepG2 and MCF-7 cells seemed not to be sufficient for CPA activation (Guo et al. 2011; Mitra et al. 2011; Olsavsky et al. 2007).

Furthermore, a H2AX phosphorylation in the nuclei of both cell lines was already observed during treatment at the lower concentration range of 4-OH-CPA UPO and PPA (Fig. 5). In contrast, the ATP assay showed no change in ATP levels at those concentrations (Fig. 4c, d). We recently found that such standard metabolic activity assays can dramatically underestimate the effects of genotoxic substances (Steinbrecht et al., 2019b). Therefore, the detection of $\gamma \mathrm{H} 2 \mathrm{AX}$ foci after drug treatment is recommended as an additional sensitive test to avoid false negative results during in vitro cytotoxicity analysis of genotoxic agents. Here we found that cytostatic and genotoxic effects of 4-OH-CPA ${ }^{\mathrm{UPO}}$ on both human cancer cell lines was nearly identical to that of commercial
PPA. This clearly demonstrate that HDMs produced by UPOs are suitable for in vitro toxicity tests.

Alcohol and aldehyde dehydrogenases (ADH, ALDH) are mainly involved in CPA detoxification by oxidizing CPA metabolites of the activation pathway to nontoxic by-products (Fig. 1). Especially ALDH enzymes are known to be distributed tissue-specifically and vary in their expression in different cell types (von Eitzen et al. 1994; Wang and Wang, 2012). Therefore, a different sensitivity to CPA and 4-OH-CPA has probably already been observed in several cells (Ohtani et al. 2006). Based on the $\mathrm{EC}_{50}$ values determined for $4-\mathrm{OH}-\mathrm{CPA}^{\mathrm{UPO}}$ and PPA, we found a higher sensitivity in MCF-7 compared to HepG2 cells (Fig. 4c, d). Even if ALDH isotypes are expressed in both cell lines, it can be assumed that ALDH activity is higher in HepG2 than in MCF-7 cells due to its liver tissue origin (Ciccone et al. 2018; Crabb et al. 2004; Guo et al. 2011; Sladek et al. 2002). If this is true, more aldophosphamide could be deactivated to carboxyphosphamide resulting in higher resistance of HepG2 cells to CPA metabolites. It is also possible that variable intracellular phosphate levels affect the decay of 4-OH-CPA to PAM and acrolein (Low et al. 1982).

In summary, we identified UPO secreted by Marasmius rotula as an efficient biocatalyst for the reproducible and selective synthesis of the known CPA metabolite 4-OH$\mathrm{CPA}$ at a semi-preparative scale. 4-OH-CPA ${ }^{\mathrm{UPO}}$ could directly be used to evaluate its cyto- and genotoxicity in cell culture experiments using a standard metabolic activity assay on ATP levels and a $\gamma \mathrm{H} 2 \mathrm{AX}$ foci test to analyze DNA double-strand break formation. Via UPOs cost-effective and efficient production of relevant HDMs is possible as demonstrated here for $4-\mathrm{OH}-\mathrm{CPA}^{\mathrm{UPO}}$ in only one simple enzymatic step. UPO-produced HDMs can thus serve as a suitable tool for metabolite risk assessment of already marketed or novel drug candidates in cell cultures or even in vivo. The large number of putative UPO sequences found in fungi and their broad catalytic spectrum represents a growing toolbox for future large-scale production of a wide range of HDMs.

\section{Acknowledgements}

We thank Stephanie Friedrich and Tino Koncz for their assistance in UPO production and purification (BTU Cottbus-Senftenberg, Germany).

\section{Authors' contributions}

SS, JK, JHK and KS conceived and designed the study. SS, JK, MT, KUS and RK performed the experiments and data analysis. SS and JK wrote the manuscript. All authors read and approved the final manuscript.

\section{Funding}

Open access funding provided by Projekt DEAL. This work was supported by the European Regional Development Fund (ERDF, Brandenburg, Germany) project "PERsonalisierte Medizin durch FUNCTIONomics in BerlinBrandenburg: Drug-Metabolisierungsmodul für Wirstofftests an Patientenzellen" (project number 85002925); and Ministry of Science, Research and Culture (MWFK, Brandenburg, Germany) project "Pilzbasierte zellfreie 
Synthese-Plattformen-PZ-Syn (project number 22-F241-03-FhG/005/001). We gratefully acknowledge MWFK for their financial support as part of the framework "Großgeräte der Länder" on acquisition of high-resolution mass spectrometry (GZ: INST 263/88-1 LAGG).

\section{Availability of data and materials}

All data and materials have been included in the main article.

\section{Ethics approval and consent to participate}

Not applicable.

\section{Consent for publication}

Not applicable.

\section{Competing interests}

The authors declare that they have no competing interests.

\section{Author details}

1 Institute of Biotechnology, Brandenburg University of Technology CottbusSenftenberg, Universitätsplatz 1, 01968 Senftenberg, Germany. ${ }^{2}$ Fraunhofer Institute for Cell Therapy and Immunology, Branch Bioanalytics and Bioprocesses, Am Mühlenberg 13, 14476 Potsdam-Golm, Germany.

Received: 26 June 2020 Accepted: 13 July 2020

Published online: 18 July 2020

\section{References}

Ahlmann M, Hempel G (2016) The effect of cyclophosphamide on the immune system: implications for clinical cancer therapy. Cancer Chemother Pharmacol 78(4):661-671. https://doi.org/10.1007/s0028 0-016-3152-1

Amadio J, Casey E, Murphy CD (2013) Filamentous fungal biofilm for production of human drug metabolites. Appl Microbiol Biotechnol 97(13):59555963. https://doi.org/10.1007/s00253-013-4833-x

Anh DH, Ullrich R, Benndorf D, Svatos A, Muck A, Hofrichter M (2007) The coprophilous mushroom Coprinus radians secretes a haloperoxidase that catalyzes aromatic peroxygenation. Appl Environ Microbiol 73(17):54775485. https://doi.org/10.1128/AEM.00026-07

Atrakchi AH (2009) Interpretation and considerations on the safety evaluation of human drug metabolites. Chem Res Toxicol 22(7):1217-1220. https:// doi.org/10.1021/tx900124j

Atzrodt J, Derdau V, Holla W, Sandvoss M (2012) The synthesis of selected phase II metabolites-O-glucuronides and sulfates of drug development candidates. Arkivoc 3:257-278. https://doi.org/10.3998/ark.55501 90.0013 .319

Baillie TA, Cayen MN, Fouda H, Gerson RJ, Green JD, Grossman SJ, Klunk LJ, LeBlanc B, Perkins DG, Shipley LA (2002) Drug metabolites in safety testing. Toxicol Appl Pharmacol 182(3):188-196. https://doi.org/10.1006/ taap. 2002.9440

Bernhardt R, Urlacher VB (2014) Cytochromes P450 as promising catalysts for biotechnological application: chances and limitations. Appl Microbiol Biotechnol 98(14):6185-6203. https://doi.org/10.1007/s00253-014-5767-7

Brandon EF, Raap CD, Meijerman I, Beijnen JH, Schellens JH (2003) An update on in vitro test methods in human hepatic drug biotransformation research: pros and cons. Toxicol Appl Pharmacol 189(3):233-246. https:// doi.org/10.1016/s0041-008x(03)00128-5

Chang TK, Weber GF, Crespi CL, Waxman DJ (1993) Differential activation of cyclophosphamide and ifosphamide by cytochromes P-450 2B and 3A in human liver microsomes. Cancer Res 53(23):5629-5637

Chang TK, Yu L, Maurel P, Waxman DJ (1997a) Enhanced cyclophosphamide and ifosfamide activation in primary human hepatocyte cultures: response to cytochrome $\mathrm{P}-450$ inducers and autoinduction by oxazaphosphorines. Cancer Res 57(10):1946-1954

Chang TK, Yu Li, Goldstein JA, Waxman DJ (1997b) Identification of the polymorphically expressed CYP2C19 and the wild-type CYP2C9-ILE359 allele as low-Km catalysts of cyclophosphamide and ifosfamide activation. Pharmacogenet Genom 7:211-221
Chen MS, White MC (2010) Combined effects on selectivity in Fe-catalyzed methylene oxidation. Science 327(5965):566-571. https://doi. org/10.1126/science. 1183602

Choi JM, Oh SJ, Lee JY, Jeon JS, Ryu CS, Kim YM, Lee K, Kim SK (2015) Prediction of drug-induced liver injury in HepG2 cells cultured with human liver microsomes. Chem Res Toxicol 28(5):872-885. https://doi.org/10.1021/ tx500504n

Ciccone V, Terzuoli E, Donnini S, Giachetti A, Morbidelli L, Ziche M (2018) Stemness marker ALDH1A1 promotes tumor angiogenesis via retinoic acid/HIF-1alpha/NEGF signalling in MCF-7 breast cancer cells. J Exp Clin Cancer Res 37(1):1-16. https://doi.org/10.1186/s13046-018-0975-0

Crabb DW, Matsumoto M, Chang D, You M (2004) Overview of the role of alcohol dehydrogenase and aldehyde dehydrogenase and their variants in the genesis of alcohol-related pathology. Proc Nutr Soc 63(1):49-63. https://doi.org/10.1079/pns2003327

de Jonge ME, Huitema AD, Rodenhuis S, Beijnen JH (2005) Clinical pharmacokinetics of cyclophosphamide. Clin Pharmacokinet 44(11):1135-1164. https://doi.org/10.2165/00003088-200544110-00003

Derdau V, Fey T, Atzrodt J (2010) Synthesis of isotopically labelled SGLT inhibitors and their metabolites. Tetrahedron 66(7):1472-1482. https://doi. org/10.1016/j.tet.2009.12.003

FDA (2016) Guidance for Industry: safety testing of drug metabolites. US Department of Health and Human Services FaDA, Center for Drug Evaluation and Research. Silver Spring, MD

Fleming RA (1997) An overview of cyclophosphamide and ifosfamide pharmacology. Pharmacotherapy 17(5 Pt 2):146S-154S

Ganesan S, Keating AF (2015) Phosphoramide mustard exposure induces DNA adduct formation and the DNA damage repair response in rat ovarian granulosa cells. Toxicol Appl Pharmacol 282(3):252-258. https://doi. org/10.1016/j.taap.2014.11.017

Genovino J, Sames D, Hamann LG, Toure BB (2016) Accessing drug metabolites via transition-metal catalyzed $\mathrm{C}-\mathrm{H}$ oxidation: the liver as synthetic inspiration. Angew Chem Int Ed 55(46):14218-14238. https://doi.org/10.1002/ anie.201602644

Gomez de Santos P, Cañellas M, Tieves F, Younes SH, Molina-Espeja P, Hofrichter M, Hollmann F, Guallar V, Alcalde M (2018) Selective synthesis of the human drug metabolite $5^{\prime}$-hydroxypropranolol by an evolved self-sufficient peroxygenase. ACS Catalysis 8(6):4789-4799. https://doi. org/10.1021/acscatal.8b01004

Gomez de Santos P, Cervantes FV, Tieves F, Plou FJ, Hollmann F, Alcalde M (2019) Benchmarking of laboratory evolved unspecific peroxygenases for the synthesis of human drug metabolites. Tetrahedron 75(13):1827-1831. https://doi.org/10.1016/j.tet.2019.02.013

Gröbe G, Ullrich R, Pecyna MJ, Kapturska D, Friedrich S, Hofrichter M, Scheibner K (2011) High-yield production of aromatic peroxygenase by the agaric fungus Marasmius rotula. AMB Express 1(1):1-11. https://doi. org/10.1186/2191-0855-1-31

Guengerich FP (2008) Cytochrome P450 and chemical toxicology. Chem Res Toxicol 21(1):70-83. https://doi.org/10.1021/tx700079z

Guo L, Dial S, Shi L, Branham W, Liu J, Fang JL, Green B, Deng H, Kaput J, Ning B (2011) Similarities and differences in the expression of drug-metabolizing enzymes between human hepatic cell lines and primary human hepatocytes. Drug Metab Dispos 39(3):528-538. https://doi.org/10.1124/ dmd. 110.035873

Hales BF (1982) Comparison of the mutagenicity and teratogenicity of cyclophosphamide and its active metabolites, 4-hydroxycyclophosphamide, phosphoramide mustard, and acrolein. Cancer Res 42(8):3016-3021

Hilton J (1984) Role of aldehyde dehydrogenase in cyclophosphamide-resistant L1210 leukemia. Cancer Res 44(11):5156-5160

Hofrichter M, Kellner H, Pecyna MJ, Ullrich R (2015) Fungal unspecific peroxygenases: heme-thiolate proteins that combine peroxidase and cytochrome P450 properties. In: Hrycay EG, Bandiera SM (eds) Monooxygenase, peroxidase and Peroxygenase properties and mechanisms of cytochrome P450. Advances in Experimental Medicine and Biology, vol 851. Springer, Cham, pp 341-368

Hofrichter M, Ullrich R (2014) Oxidations catalyzed by fungal peroxygenases. Curr Opin Chem Biol 19:116-125. https://doi.org/10.1016/j. cbpa.2014.01.015

Hofrichter M, Ullrich R, Pecyna MJ, Liers C, Lundell T (2010) New and classic families of secreted fungal heme peroxidases. Appl Microbiol Biotechnol 87(3):871-897. https://doi.org/10.1007/s00253-010-2633-0 
Hohorst HJ, Peter G, Struck RF (1976) Synthesis of 4-hydroperoxy derivatives of ifosfamide and trofosfamide by direct ozonation and preliminary antitumor evaluation in vivo. Cancer Res 36(7 PT 1):2278-2281

Javitt NB (1990) Hep-G2 cells as a resource for metabolic studies - lipoprotein, cholesterol, and bile-acids. FASEB J 4(2):161-168

Johansson M, Bielenstein M (1994) Determination of 4-hydroxycyclophosphamide in plasma, as 2,4-dinitrophenylhydrazone derivative of aldophosphamide, by liquid-chromatography. J Chromatogr B 660(1):111-120. https://doi.org/10.1016/0378-4347(94)00283-5

Kars MD, Iseri OD, Gunduz U, Ural AU, Arpaci F, Molnar J (2006) Development of rational in vitro models for drug resistance in breast cancer and modulation of MDR by selected compounds. Anticancer Res 26(6B):4559-4568

Kiebist J, Hofrichter M, Zuhse R, Scheibner K (2019) Oxyfunctionalization of pharmaceuticals by fungal peroxygenases. In: Grunwald P (ed) Pharmaceutical Biocatalysis: Chemoenzymatic of Active Pharmaceutical Ingredients, vol 1. Jenny Stanford Publishing Pte Ltd, Singapore

Kiebist J, Holla W, Heidrich J, Poraj-Kobielska M, Sandvoss M, Simonis R, Grobe G, Atzrodt J, Hofrichter M, Scheibner K (2015) One-pot synthesis of human metabolites of SAR548304 by fungal peroxygenases. Bioorg Med Chem 23(15):4324-4332. https://doi.org/10.1016/j.bmc.2015.06.035

Kiebist J, Schmidtke KU, Zimmermann J, Kellner H, Jehmlich N, Ullrich R, Zander D, Hofrichter M, Scheibner K (2017) A peroxygenase from Chaetomium globosum catalyzes the selective oxygenation of testosterone. ChemBioChem 18(6):563-569. https://doi.org/10.1002/cbic.201600677

Kinne M, Poraj-Kobielska M, Aranda E, Ullrich R, Hammel KE, Scheibner K, Hofrichter M (2009) Regioselective preparation of 5-hydroxypropranolol and 4'-hydroxydiclofenac with a fungal peroxygenase. Bioorg Med Chem Lett 19(11):3085-3087. https://doi.org/10.1016/j.bmcl.2009.04.015

Kirchmair J, Göller AH, Lang D, Kunze J, Testa B, Wilson ID, Glen RC, Schneider G (2015) Predicting drug metabolism: experiment and/or computation? Nat Rev Drug Discov 14(6):387-404. https://doi.org/10.1038/nrd4581

Knowles BB, Howe CC, Aden DP (1980) Human hepatocellular carcinoma cell lines secrete the major plasma proteins and hepatitis B surface antigen. Science 209(4455):497-499. https://doi.org/10.1126/science.6248960

Li J, Xu LZ, He KL, Guo WJ, Zheng YH, Xia P, Chen Y (2001) Reversal effects of nomegestrol acetate on multidrug resistance in adriamycin-resistant MCF7 breast cancer cell line. Breast Cancer Res 3(4):253-263. https://doi. org/10.1186/bcr303

Litvinas ND, Brodsky BH, Du Bois J (2009) C-H hydroxylation using a heterocyclic catalyst and aqueous $\mathrm{H}_{2} \mathrm{O}_{2}$. Angew Chem Int Ed 48(25):4513-4516. https://doi.org/10.1002/anie.200901353

Low JE, Borch RF, Sladek NE (1982) Conversion of 4-Hydroperoxycyclophosphamide and 4-Hydroxycyclophosphamide to Phosphoramide Mustard and Acrolein Mediated by Bifunctional Catalysts. Cancer Res 42(3):830-837

Madsen KG, Olsen J, Skonberg C, Hansen SH, Jurva U (2007) Development and evaluation of an electrochemical method for studying reactive phase-I metabolites: correlation to in vitro drug metabolism. Chem Res Toxicol 20(5):821-831. https://doi.org/10.1021/tx700029u

Masood MA, Farrant E, Morao I, Bazin M, Perez M, Bunnage ME, Fancy SA, Peakman T (2012) Lead diversification. Application to existing drug molecules: Mifepristone 1 and antalarmin 8. Bioorg Med Chem Lett 22(1):723-728. https://doi.org/10.1016/j.bmcl.2011.10.066

Mitra R, Guo Z, Milani M, Mesaros C, Rodriguez M, Nguyen J, Luo X, Clarke D, Lamba J, Schuetz E, Donner DB, Puli N, Falck JR, Capdevila J, Gupta K, Blair IA, Potter DA (2011) CYP3A4 mediates growth of estrogen receptorpositive breast cancer cells in part by inducing nuclear translocation of phospho-Stat3 through biosynthesis of (+/-)-14,15-epoxyeicosatrienoic acid (EET). J Biol Chem 286(20):17543-17559. https://doi.org/10.1074/jbc M1 10.198515

Molina-Espeja P, Garcia-Ruiz E, Gonzalez-Perez D, Ullrich R, Hofrichter M, Alcalde M (2014) Directed evolution of unspecific peroxygenase from Agrocybe aegerita. Appl Environ Microbiol 80(11):3496-3507. https://doi org/10.1128/AEM.00490-14

Molina-Espeja P, Ma S, Mate DM, Ludwig R, Alcalde M (2015) Tandem-yeast expression system for engineering and producing unspecific peroxygenase. Enzyme Microb Technol 73-74:29-33. https://doi.org/10.1016/j. enzmictec.2015.03.004

Nedderman AN (2009) Metabolites in safety testing: metabolite identification strategies in discovery and development. Biopharm Drug Dispos 30(4):153-162. https://doi.org/10.1002/bdd.660
Nicolas I, Bijani C, Brasseur D, Pratviel G, Bernadou J, Robert A (2013) Metalloporphyrin-catalyzed hydroxylation of the N, N-dimethylamide function of the drug molecule SSR180575 to a stable N-methyl-N-carbinolamide. Cr Chim 16(11):1002-1007. https://doi.org/10.1016/j.crci.2013.05.001

Nouri-Nigjeh E, Permentier HP, Bischoff R, Bruins AP (2010) Lidocaine oxidation by electrogenerated reactive oxygen species in the light of oxidative drug metabolism. Anal Chem 82(18):7625-7633. https://doi.org/10.1021/ ac101364s

Ohtani T, Nakamura T, Toda K, Furukawa F (2006) Cyclophosphamide enhances TNF-alpha-induced apoptotic cell death in murine vascular endothelial cell. FEBS Lett 580(6):1597-1600. https://doi.org/10.1016/j.febs| et.2006.01.092

Olsavsky KM, Page JL, Johnson MC, Zarbl H, Strom SC, Omiecinski CJ (2007) Gene expression profiling and differentiation assessment in primary human hepatocyte cultures, established hepatoma cell lines, and human liver tissues. Toxicol Appl Pharmacol 222(1):42-56. https://doi. org/10.1016/j.taap.2007.03.032

Omole JG, Ayoka OA, Alabi QK, Adefisayo MA, Asafa MA, Olubunmi BO, Fadeyi BA (2018) Protective effect of kolaviron on cyclophosphamide-induced cardiac toxicity in rats. J Evid Based Integr Med 23:1-11. https://doi. org/10.1177/2156587218757649

Park BK, Boobis A, Clarke S, Goldring CE, Jones D, Kenna JG, Lambert C, Laverty HG, Naisbitt DJ, Nelson S, Nicoll-Griffith DA, Obach RS, Routledge P, Smith DA, Tweedie DJ, Vermeulen N, Williams DP, Wilson ID, Baillie TA (2011) Managing the challenge of chemically reactive metabolites in drug development. Nat Rev Drug Discov 10(4):292-306. https://doi. org/10.1038/nrd3408

Pervaiz I, Ahmad S, Madni MA, Ahmad H, Khaliq FH (2013) Microbial biotransformation: a tool for drug designing (Review). Prikl Biokhim Mikrobiol 49(5):435-449. https://doi.org/10.7868/s0555109913050097

Peter G, Hohorst HJ (1979) Synthesis and preliminary antitumor evaluation of 4-(SR)-sulfido-cyclophosphamides. Cancer Chemother Pharmacol 3(3):181-188. https://doi.org/10.1007/bf00262420

Piera J, Baeckvall JE (2008) Catalytic oxidation of organic substrates by molecular oxygen and hydrogen peroxide by multistep electron transfer-a biomimetic approach. Angew Chem Int Ed 47(19):3506-3523

Poraj-Kobielska M, Atzrodt J, Holla W, Sandvoss M, Grobe G, Scheibner K, Hofrichter M (2013) Preparation of labeled human drug metabolites and drug-drug interaction-probes with fungal peroxygenases. J Labelled Comp Radiopharm 56(9-10):513-519. https://doi.org/10.1002/jlcr.3103

Poraj-Kobielska M, Kinne M, Ullrich R, Scheibner K, Kayser G, Hammel KE, Hofrichter M (2011) Preparation of human drug metabolites using fungal peroxygenases. Biochem Pharmacol 82(7):789-796. https://doi. org/10.1016/j.bcp.2011.06.020

Prados J, Melguizo C, Rama AR, Ortiz R, Segura A, Boulaiz H, Velez C, Caba O, Ramos JL, Aranega A (2010) Gef gene therapy enhances the therapeutic efficacy of doxorubicin to combat growth of MCF-7 breast cancer cells. Cancer Chemother Pharmacol 66(1):69-78. https://doi.org/10.1007/s0028 0-009-1135-1

Ren S, Yang JS, Kalhorn TF, Slattery JT (1997) Oxidation of cyclophosphamide to 4-hydroxycyclophosphamide and deschloroethylcyclophosphamide in human liver microsomes. Cancer Res 57(19):4229-4235

Rodriguez-Antona C, Ingelman-Sundberg M (2006) Cytochrome P450 pharmacogenetics and cancer. Oncogene 25(11):1679-1691. https://doi. org/10.1038/sj.onc.1209377

Sawayama AM, Chen MM, Kulanthaivel P, Kuo MS, Hemmerle H, Arnold FH (2009) A panel of cytochrome P450 BM3 variants to produce drug metabolites and diversify lead compounds. Chem-Eur J 15(43):1172311729. https://doi.org/10.1002/chem.200900643

Schadt S, Bister B, Chowdhury SK, Funk C, Hop CE, Humphreys WG, Igarashi F, James AD, Kagan M, Khojasteh SC (2018) A decade in the MIST: learnings from investigations of drug metabolites in drug development under the "metabolites in safety testing" regulatory guidance. Drug Metab Dispos 46(6):865-878

Scharer OD (2005) DNA interstrand crosslinks: natural and drug-induced DNA adducts that induce unique cellular responses. ChemBioChem 6(1):27-32. https://doi.org/10.1002/cbic.200400287

Schroer K, Kittelmann M, Lutz S (2010) Recombinant human cytochrome P450 monooxygenases for drug metabolite synthesis. Biotechnol Bioeng 106(5):699-706. https://doi.org/10.1002/bit.22775 
Shan G, Yang X, Ma L, Rao Y (2012) Pd-catalyzed C-H oxygenation with TFA TFAA: expedient access to oxygen-containing heterocycles and latestage drug modification. Angew Chem Int Ed 51(52):13070-13074. https ://doi.org/10.1002/anie.201207458

Shui-Tein Chen T-LP, Tsai Y-C, Huang C-M (2002) Proteomics reveals protein profile changes in doxorubicin — treated MCF-7 human breast cancer cells. Cancer Lett. https://doi.org/10.1016/s0304-3835(02)00025 -3(181):95-107.10.1016/s0304-3835(02)00025-3

Sladek NE, Kollander R, Sreerama L, Kiang DT (2002) Cellular levels of aldehyde dehydrogenases (ALDH1A1 and ALDH3A1) as predictors of therapeutic responses to cyclophosphamide-based chemotherapy of breast cancer: a retrospective study. Rational individualization of oxazaphosphorinebased cancer chemotherapeutic regimens. Cancer Chemother Pharmacol 49(4):309-321. https://doi.org/10.1007/s00280-001-0412-4

Steinbrecht S, Kammerer S, Küpper JH (2019a) HepG2 cells with recombinant cytochrome P450 enzyme overexpression: Their use and limitation as in vitro liver model. J Cell Biot 5(1):55-64. https://doi.org/10.3233/jcb189013

Steinbrecht S, Konig R, Schmidtke KU, Herzog N, Scheibner K, Kruger-Genge A, Jung F, Kammerer S, Kupper JH (2019b) Metabolic activity testing can underestimate acute drug cytotoxicity as revealed by HepG2 cell clones overexpressing cytochrome P450 2C19 and 3A4. Toxicology 412:37-47. https://doi.org/10.1016/j.tox.2018.11.008

Takamizawa A, Matsumoto S, Iwata T, Tochino Y, Katagiri K, Yamaguchi K, Shiratori O (1975) Studies on cyclophosphamide metabolites and their related compounds. 2. Preparation of an active species of cyclophosphamide and related compounds. J Med Chem 18(4):376-383. https://doi. org/10.1021/jm00238a011

Trebunova M, Laputkova G, Slaba E, Lacjakova K, Verebova A (2012) Effects of docetaxel, doxorubicin and cyclophosphamide on human breast cancer cell line MCF-7. Anticancer Res 32(7):2849-2854

Ullrich R, Nuske J, Scheibner K, Spantzel J, Hofrichter M (2004) Novel haloperoxidase from the agaric basidiomycete Agrocybe aegerita oxidizes aryl alcohols and aldehydes. Appl Environ Microbiol 70(8):4575-4581. https:// doi.org/10.1128/AEM.70.8.4575-4581.2004
Urlacher VB, Girhard M (2012) Cytochrome P450 monooxygenases: an update on perspectives for synthetic application. Trends Biotechnol 30(1):26-36. https://doi.org/10.1016/j.tibtech.2011.06.012

van der Steen J, Timmer EC, Westra JG, Benckhuysen C (1973) 4-hydroperoxidation in the fenton oxidation of the antitumor agent cyclophosphamide. J Am Chem Soc 95(22):7535-7536

von Eitzen U, Meier-Tackmann D, Agarwal DP, Goedde HW (1994) Detoxification of cyclophosphamide by human aldehyde dehydrogenase isozymes. Cancer Lett 76(1):45-49. https://doi.org/10.1016/0304-3835(94)90132-5

Walker D, Brady J, Dalvie D, Davis J, Dowty M, Duncan JN, Nedderman A, Obach RS, Wright P (2009) A holistic strategy for characterizing the safety of metabolites through drug discovery and development. Chem Res Toxicol 22(10):1653-1662. https://doi.org/10.1021/tx900213j

Wang D, Wang H (2012) Oxazaphosphorine bioactivation and detoxification. The role of xenobiotic receptors. Acta Pharm Sin B 2(2):107-117. https:// doi.org/10.1016/j.apsb.2012.02.004

Xie HJ, Yasar U, Lundgren S, Griskevicius L, Terelius Y, Hassan M, Rane A (2003) Role of polymorphic human CYP2B6 in cyclophosphamide bioactivation Pharmacogenomics J 3(1):53-61. https://doi.org/10.1038/sj.tpj.6500157

Yokoyama Y, Sasaki Y, Terasaki N, Kawataki T, Takekawa K, Iwase Y, Shimizu T, Sanoh S, Ohta S (2018) Comparison of drug metabolism and its related hepatotoxic effects in HepaRG, cryopreserved human hepatocytes, and HepG2 cell cultures. Biol Pharm Bull 41(5):722-732. https://doi. org/10.1248/bpb.b17-00913

Zollner A, Buchheit D, Meyer MR, Maurer HH, Peters FT, Bureik M (2010) Production of human phase 1 and 2 metabolites by whole-cell biotransformation with recombinant microbes. Bioanalysis 2(7):1277-1290. https:// doi.org/10.4155/Bio.10.80

\section{Publisher's Note}

Springer Nature remains neutral with regard to jurisdictional claims in published maps and institutional affiliations.

\section{Submit your manuscript to a SpringerOpen ${ }^{\circ}$ journal and benefit from:}

- Convenient online submission

- Rigorous peer review

- Open access: articles freely available online

- High visibility within the field

- Retaining the copyright to your article

Submit your next manuscript at $\boldsymbol{\nabla}$ springeropen.com 